\title{
Effect of Baked, Whipped and Fermentation on Antioxidant Activity in Red Raspberries \\ Darwish $\mathrm{AZ}^{1 *}$, Bayomy $\mathrm{H}^{2}$ and Rozan $\mathrm{M}^{2}$
}

${ }^{1}$ Dairy Science Department, Faculty of Agriculture, Assiut University, Egypt

${ }^{2}$ Food Science and Technology Department, Faculty of Agriculture, Damanhour University, Behira, Egypt

\begin{abstract}
Red raspberries (Rubus idaeus) are a good source of antioxidants and contains appreciable levels of phenolic compounds (TPC). Adding raspberry to the product are attributed the most significant health benefits of to the phenolic compounds. This study examined the three different manufacturing processes baked, whipped and fermentation on antioxidant activity in red raspberry. The phenolic compounds in red raspberry, sponge cake, whipping cream and yoghurt by red raspberry were determined by HPLC. Sensory evaluation found that the best proportions to add red raspberry to whipped cream and yogurt is $10 \%$ but in the sponge cake is $15 \%$. The total phenols were $56 \%, 37 \%$ and $4 \%, 3 \%$ of red raspberry, red raspberry-yoghurt, red raspberry-whipped cream and red raspberry-sponge cake respectively. So the treatments were order in general to their effect of the TPC: fermentation > whipped > baked.
\end{abstract}

Keywords: Antioxidant; Baked; Fermentation; Red raspberry; Whipped

\section{Introduction}

Recently, Plants of the genus Rubus (family: Rosaceae) have been reported to exhibit several biological activities such as anti-diabetic, anti-oxidative, anti-inflammatory and anti-hyperlipidemic activities. These biological activities were due to their polyphenol components including anthocyanins present in some of the varieties [1]. Red raspberries (Rubus idaeus) are among the fruits containing the highest antioxidant levels. In addition to vitamin $\mathrm{C}$, the antioxidant activity of red raspberries is primarily constituted by two classes of compounds: anthocyanins and ellagitannins. Ellagitannins, which are complex derivatives of ellagic acid [2], have been identified in tea, many medicinal plants, and several fruits, including raspberries [3,4]. In addition to their vasorelaxation properties [5], ellagitannins have been described to have general antioxidant effects [6]. Red raspberry could therefore be considered as a model fruit source for a variety of potentially healthy compounds [7]. Berries, fruits full of bioactive compounds, are also very delicious, have low energy [8]. To the bioactive compounds group in berries belong antioxidants such as phenolic compounds and fruit colorants (anthocyanins and carotenoids). Berries' phenolics represent a diverse group of compounds including phenolic acids, such as hydroxybenzoic and hydroxycinnamic acid conjugates; flavonoids, such as flavonols, flavanols, and anthocyanins. In addition, tannins, divided into condensed tannins (proanthocyanidins) and hydrolyzable tannins, are reported to be important bioactive compounds. These compounds are of great interest for nutritionists and food technologists due to the opportunity to use bioactive compounds as functional foods ingredients. Nutraceuticals and functional foods have become very popular for people due to the consumer demands for healthy nutraceutical foods that could possibly reduce some health risks and improve various health conditions [9]. The anthocyanins are stable at low temperatures and in the dark [10]. The highest temperature combined with a short baking time had the best effect on the preservation of polyphenols, in order to achieve the most favorable nutritional effect of baked products enriched with fruit pomace [11]. $\mathrm{pH}$ is closely related to microbial growth and the structural changes in phytochemicals during fermentation. For example, anthocyanin breakdown is dependent on the $\mathrm{pH}$ in the presence of oxygen, is also directly related to the level of pseudo base, and is inversely related to the cation concentration [12]. Several studies $[13,14]$ have shown that anthocyanins are stable at low $\mathrm{pH}$. Anthocyanins exhibit the highest stability, with the red flavylium cation stable around $\mathrm{pH}$ 1-2 [14]. The stability of anthocyanins is dependent on their structure; for instance, acylated anthocyanins are more stable than the non-acylated forms [15]. $\mathrm{pH}$ is a dominant factor in the radical scavenging capacity of wine anthocyanins, as an increase in $\mathrm{pH}$ often increases the capacity for radical scavenging [16]. Colour plays a very important role in the acceptability of some foods by many consumers [17]. In practice, most manufacturers tend to colour products which have dull colours and look unappealing to most consumers. Synthetic colourants have often been used in attempts to colour some foods and beverages [18]. However, the demand for foods with synthetic anthocyanins are a great interest as alternatives to synthetic colourants due to their bright colours and associated health benefits $[19,20]$. They are considered to be safe because they have been consumed for centuries in fruits, and vegetables without any health risks [21]. Whole fruit extracts containing non-acylated anthocyanins from Berberis boliviana L. showed improved colour and pigment stability when incorporated in yoghurt [22]. The anthocyanins are stable at low temperatures and in the dark [10] For that we believe that whole fruit juice extracts from red raspberries (Rubus idaeus) could serve as an appropriate colorant and nutraceautical in yoghurt. Raspberry fruits are rich in phenolic compounds contents such as phenolic acids [23,24] flavonoids [24,25] and anthocyanins [23]. The phenolic compounds in berries have been reported to have antioxidant, anticancer, antiinflammatory, and antineurodegenerative biological properties $[26,27]$. In recent years, red raspberry anthocyanins have in many occasions been applied in baked foods, and confectioneries [28]. In this study, we decided to investigate whether anthocyanins from Red raspberry (Rubus idaeus)

*Corresponding author: Darwish AZ, Dairy Science Department, Faculty of Agriculture, Assiut University, Egypt, Tel: +0882331384; E-mail: zahraadarwish@ yahoo.com

Received August 30, 2016; Accepted September 17, 2016; Published September 23, 2016

Citation: Darwish AZ, Bayomy H, Rozan M (2016) Effect of Baked, Whipped and Fermentation on Antioxidant Activity in Red Raspberries. J Food Process Technol 7: 621 doi: 10.4172/2157-7110.1000621

Copyright: (C) 2016 Darwish AZ, et al. This is an open-access article distributed under the terms of the Creative Commons Attribution License, which permits unrestricted use, distribution, and reproduction in any medium, provided the original author and source are credited. 
could be used as potential colour additives in yoghurt since yoghurt has a low $\mathrm{pH}$ and it is stored under refrigerated conditions. Therefore, the current study was undertaken to use the red raspberries (Rubus idaeus) in industry of yoghurt, cake and the formation of cream as colorant. And study the effect of these processes on the antioxidant activity.

\section{Methods}

\section{Materials}

Whipping cream from the brand Almarai (Kingdom of Saudi Arabia) was purchased from the local supermarket. This is an ultrahigh temperature (UHT) product containing $33 \%$ milk fat, $1.9 \%$ protein and $3.5 \%$ carbohydrate. Cream was kept in fridge at $5^{\circ} \mathrm{C}$ or below during storage. Commercial wheat flour was purchased from Kuwait Flour mills \& Bakeries Co. (Kuwait). Sunflower oil, sucrose, batter and fresh eggs were purchased from local market in Tabuk, Kingdom of Saudi Arabia.

\section{Sponge cake preparation}

The sponge cakes were prepared according to Chaiya and Pongsawatmanit [29]. The experiments used sponge cake batter formulations containing WF (50-100 g), $140 \mathrm{~g}$ liquid whole eggs, 10 $\mathrm{g}$ whole milk powder, $2 \mathrm{~g}$ baking powder, $120 \mathrm{~g}$ sugar, $80 \mathrm{~g}$ butter and $40 \mathrm{~g}$ water. In the cake batter preparation $\sim 500 \mathrm{~g}$ ), the liquid whole eggs, water, sugar were mixed in a using Kenwood-kitchen machine $1200 \mathrm{~W}$ (Chine) with machine speeds from 1 to 10 at speed 3 for 1 min and further mixed at speed 6 for $9 \mathrm{~min}$. Then, dry ingredients (the flour blend of WF, whole milk powder and baking powder) were added simultaneously to the mixture at speed 1 for $1 \mathrm{~min}$ and further mixed at speed 3 for $2 \mathrm{~min}$. The melted butter was added finally and mixed at speed 1 for $20 \mathrm{~s}$. The batter was divided into four portions formulation each one $125 \mathrm{~g}$ (control and three with red raspberry puree as following: red raspberry spongy cake $10 \%(12.5 \mathrm{~g})$, red raspberry spongy cake $15 \%$ (18.75 g) and red raspberry spongy cake 25\% (31.25 g). Each one was placed in pan $(8.5 \times 16 \times 5 \mathrm{~cm})$ and baked in oven at $175^{\circ} \mathrm{C}$ for $20 \mathrm{~min}$. After baking, the cakes were removed from the pans, cooled upside down on a wire rack for $30 \mathrm{~min}$ at room temperature and kept in plastic bags to prevent drying before being measured for sensory evaluation within $12 \mathrm{~h}$.

\section{Whipped cream preparing}

Cream must be kept in fridge at least $24 \mathrm{~h}$ before tempering. In each experiment, $100 \mathrm{ml}$ cream was mixed with different mount of raspberry puree $(5,10$ and $15 \mathrm{~g})$ using Kenwood-kitchen machine 1200 W (Chine).

\section{Yoghurt preparing}

Yoghurt was manufactured using lactobacillus delbrueckii supsp bulgaricus and streptococcus salivarious subsp thermophilus (1:1) commercial starter culture. Fresh cow's milk was heated to $90^{\circ} \mathrm{C}$ for $10 \mathrm{~min}$, and cooled to $42^{\circ} \mathrm{C}$. Milk was mixed with different percentage of red raspberry (5, 10 and 15\%) after that adding 3\% starter and incubated at same temperature.

\section{Proximate analysis}

Materials (red raspberry puree, cream, yoghurt and sponge cake) were dried at $70^{\circ} \mathrm{C}$ to a constant weight, moisture contents, ash, and crude fiber were determined by AOAC [30] methods. Total lipids from the samples were extracted with chloroform/methanol $(2: 1, \mathrm{v} / \mathrm{v})$ and quantified gravimetrically [31]. Nitrogen content $(\mathrm{N})$ of the sample was estimated by the method described by Kjeldahl [32] and crude protein was calculated as $\mathrm{N} \times 6.25$ [33]. The amount of total carbohydrates was obtained by the difference between weight of the sample taken and sum of its moisture, ash, total lipid, protein, and fiber contents [34].

\section{Analysis of total phenolic content}

The total phenolic content was determined according to the FolinCiocalteu procedure [35]. Briefly, the extract $(500 \mu \mathrm{l})$ was transferred into a test tube and oxidized with the addition of $250 \mu \mathrm{l}$ of FolinCiocalteu reagent. After $5 \mathrm{~min}$, the mixture was neutralized with 1.25 $\mathrm{ml}$ of $20 \%$ aqueous $\mathrm{Na}_{2} \mathrm{CO}_{3}$ solution. After $40 \mathrm{~min}$, the absorbance was measured at $725 \mathrm{~nm}$ against the solvent blank. The total phenolic content was determined by means of a calibration curve prepared with gallic acid, and expressed as $\mu$ g of gallic acid equivalent (GAE) per ml of sample.

\section{Analysis of total flavonoid content}

The total flavonoid content was determined according to Zilic et al. [35]. Briefly, $250 \mu \mathrm{l}$ of $5 \% \mathrm{NaNO}_{2}$ was mixed with $500 \mu \mathrm{l}$ of extract. After $6 \mathrm{~min}, 2.5 \mathrm{ml}$ of a $10 \% \mathrm{AlCl}_{3}$ solution was added. After $7 \mathrm{~min}, 1.25$ $\mathrm{ml}$ of $1 \mathrm{M} \mathrm{NaOH}$ was added, and the mixture was centrifuged at 5000 $\mathrm{g}$ for $10 \mathrm{~min}$. Absorbance of the supernatant was measured at $510 \mathrm{~nm}$ against the solvent blank. The total flavonoid content was expressed as $\mu \mathrm{g}$ of catechin equivalent (CE) per $\mathrm{ml}$ of sample.

\section{Determination of radical DPPH scavenging activity}

Free radical scavenging capacity was determined using the stable 1,1-Diphenyl-2-picryl-hydrazyl (DPPH') according to Hwang and Thi [36]. The final concentration was $50 \mu \mathrm{M}$ for DPPH and the final reaction volume was $3.0 \mathrm{ml}$. The absorbance at $517 \mathrm{~nm}$ was measured against a blank of pure methanol at $60 \mathrm{~min}$. Percent inhibition of the DPPH free radical was calculated by the following equation:

$$
\text { Inhibition }(\%)=100 \times\left(\mathrm{A}_{\text {control }}-\mathrm{A}_{\text {sample }}\right) / \mathrm{A}_{\text {control }}
$$

Where

$\mathrm{A}_{\text {control }}$ is the absorbance of the control reaction (containing all reagents except the test compound).

$\mathrm{A}_{\text {sample }}$ is the absorbance of the test compound. Also, the antioxidant activity was determined by means of a calibration curve prepared with Trolox, and expressed as mg of Trolox equivalent (TE) per unit (volume or weight) of sample.

\section{Phenolic acids profile}

Extraction of phenolic compounds: The sample was alkaline hydrolyzed according to Kim et al. [37]. Sample (1 g) was placed in quick fit conical flask and $20 \mathrm{ml}$ of $2 \mathrm{M} \mathrm{NaOH}$ was added and the flasks were flushed with $\mathrm{N}_{2}$ and the stopper was replaced. The samples were shacked for $4 \mathrm{~h}$ at room temperature. The $\mathrm{pH}$ was adjusted to 2 with $6 \mathrm{M} \mathrm{HCl}$. The samples were centrifuged at $5000 \mathrm{rpm}$ for $10 \mathrm{~min}$ and the supernatant was collected. Phenolic compounds were extracted twice with $50 \mathrm{ml}$ ethyl ether and ethyl acetate $1: 1$. The organic phase was separated and evaporated at $45^{\circ} \mathrm{C}$ and the samples redissolved in $2 \mathrm{ml}$ methanol.

Analysis of phenolic compounds by HPLC: HPLC analysis was carried out using Agilent Technologies 1100 series liquid chromatograph equipped with an auto sampler and a diode-array detector. The analytical column was an Eclipse XDB-C18 $(150 \times 4.6$ $\mu \mathrm{m} ; 5 \mu \mathrm{m}$ ) with a C18 guard column (Phenomenex, Torrance, CA). The mobile phase consisted of acetonitrile (solvent $\mathrm{A}$ ) and $2 \%$ acetic acid in water (v/v) (solvent B). The flow rate was kept at $0.8 \mathrm{ml} / \mathrm{min}$ for a total 
run time of $70 \mathrm{~min}$ and the gradient programme was as follows: $100 \% \mathrm{~B}$ to $85 \% \mathrm{~B}$ in $30 \mathrm{~min}, 85 \% \mathrm{~B}$ to $50 \% \mathrm{~B}$ in $20 \mathrm{~min}, 50 \% \mathrm{~B}$ to $0 \% \mathrm{~B}$ in $5 \mathrm{~min}$ and $0 \% \mathrm{~B}$ to $100 \% \mathrm{~B}$ in $5 \mathrm{~min}$. The injection volume was $50 \mu \mathrm{l}$ and peaks were monitored simultaneously at 280 and $320 \mathrm{~nm}$ for the benzoic acid and cinnamic acid derivatives, respectively. All samples were filtered through a $0.45 \mu \mathrm{m}$ Acrodisc syringe filter (Gelman Laboratory, MI) before injection. Peaks were identified by congruent retention times and UV spectra and compared with those of the standards.

\section{Sensory evaluation}

The hedonic test was used to determine the degree of overall liking for the whipped cream, sponge cake and yogurt. For this study, untrained consumers were recruited from the students, staff. All consumers were interested volunteers and informed that they would be evaluating whipped cream, sponge cake and yogurt. 15 consumers ( 7 males and 8 females, $19-55$ years) received samples were asked to rate them based on degree of liking on a seven-point hedonic scale (1 = dislike extremely, 4 = neither like nor dislike, 7 = like extremely). Samples were placed on white plates and identified with random numbers. Panelists evaluated the samples in a testing area and were instructed to rinse their mouths with water between samples to minimize any residual effect [38]. Where the evaluation in terms of color, taste and smell and textures in addition to the overall acceptance.

\section{Statistical analysis}

Statistical analysis of experimental data was performed by analysis of variance (ANOVA) producers using SPSS version 9.0 program to examine statistical significance differences of sensory analysis means of experimental data. Results were considered statistically significant when $\mathrm{p}<0.05$. Mean \pm standard deviation values were also presented.

\section{Results and Discussion}

\section{Sensory evaluation}

Results of sensory evaluation for reach to the best proportions to add red raspberry to whipped cream, sponge cake and yogurt are reported in Table 1. When evaluated by untrained consumers, statistically significant differences were detected in all of the sensory attributes evaluated $(\mathrm{P} \leq 0.05)$. It is clear that the best proportions to add red raspberry to whipped cream and yogurt is $10 \%$ but in the sponge cake is $15 \%$. With regard to color, taste, smell texture and the overall acceptance $10 \%$ red raspberry whipped cream, $10 \%$ red raspberry yogurt and $15 \%$ red raspberry sponge cake were appreciated the most significantly higher preference scores than the other treatments $(\mathrm{P} \leq$ $0.05)$.

\section{Proximate composition}

Table 2 describes the proximate composition of red raspberry puree and foods that have been selected from the sensory evaluation, which have ratios of red raspberry. These foods include whipped cream (with $10 \%$ red raspberry), yoghurt (with $10 \%$ red raspberry) and sponge cake (with 15\% red raspberry).

\section{Total phenolic content}

The total phenolic content (TPC) for sponge cake, yoghurt and whipped cream (Table 3). Highest TPC in samples was found in sponge cake $(0.709 \pm 0.08 \mathrm{mg} \mathrm{GEA} / \mathrm{ml})$ which were hated at $175^{\circ} \mathrm{C}$ for $20 \mathrm{~min}$. that may case decreasing percentage in TPC than red raspberry because though heat-treated lowered the antioxidant level, and adding ingredients such as sugar diluted the antioxidant concentration, products made from berries are high sources of antioxidants [39-41]. The highest value compare with yogurt and whipped cream may be due to the production of Maillard reaction products in the crust during thermal processing [42]. Similar observations have been made when baking rhubarb, whereby both TPC and FRAP AA were higher during the first $20 \mathrm{~min}$ and then decreased to low levels [43] and when baking chocolate cookies and chocolate cakes made with baking powder rather than baking soda [44]. TPC in red raspberry-whipped cream was 0.081 $\pm 0.004 \mathrm{mg}$ GEA $/ \mathrm{ml}$ decreasing percentage in TPC this may be due to whipped processes. Yogurt has recorded the lowest content of TPC $0.067 \pm 0.001 \mathrm{mg}$ GEA $/ \mathrm{ml}$. During fermentation process microbial yoghurt utilization of phenolic acids such as ferulic and p-coumaric acid and post acidification lead to the production of other phenolic acids such as vanillic and p-hydroxybenzoic acids before the aromatic ring structure is broken down [45]. Also the decreasing of TPC than the red raspberry there were increasing in the TPC red raspberry-yogurts than plain-yoghurt $0.008 \mathrm{mg} \mathrm{GEA} / \mathrm{ml}$ that can be explained by the presence of indigenous phytochemical compounds in raspberry (e.g., flavonoids and phenolic compounds) [46]. The major TPC were 63.929 $\pm 3.000,46.162 \pm 5.100,38.617 \pm 5.000$ and $11.320 \pm 1.000 \mathrm{ug} / \mathrm{g}$ of gallic

\begin{tabular}{|c|c|c|c|c|c|c|c|c|c|}
\hline & \multicolumn{3}{|c|}{ Whipped cream } & \multicolumn{3}{|c|}{ Sponge cake } & \multicolumn{3}{|c|}{ Yogurt } \\
\hline & $5 \%$ & $10 \%$ & $15 \%$ & $5 \%$ & $10 \%$ & $15 \%$ & $5 \%$ & $10 \%$ & $15 \%$ \\
\hline Color & $7.4 \pm 0.06^{c}$ & $9.4 \pm 0.02^{\mathrm{a}}$ & $8.3 \pm 0.03^{b}$ & $7.3 \pm 0.04^{b}$ & $7.4 \pm 0.05^{b}$ & $8.7 \pm 0.04^{a}$ & $5.7 \pm 0.06^{c}$ & $8.8 \pm 0.03^{a}$ & $7.1 \pm 0.01^{b}$ \\
\hline Taste & $8.3 \pm 0.02^{b}$ & $9.2 \pm 0.02^{\mathrm{a}}$ & $8.7 \pm 0.05^{b}$ & $6.3 \pm 0.07^{a}$ & $6.8 \pm 0.07^{a}$ & $6.5 \pm 0.07^{a}$ & $8.4 \pm 0.03^{b}$ & $9.5 \pm 0.02^{\mathrm{a}}$ & $9.5 \pm 0.02^{\mathrm{a}}$ \\
\hline Smell & $8.0 \pm 0.04^{b}$ & $9.3 \pm 0.03^{a}$ & $9.2 \pm 0.03^{a}$ & $6.1 \pm 0.05^{b}$ & $6.3 \pm 0.03^{b}$ & $8.7 \pm 0.06^{a}$ & $7.6 \pm 0.04^{b}$ & $8.4 \pm 0.04 a^{b}$ & $8.7 \pm 0.02^{a}$ \\
\hline Texture & $7.9 \pm 0.04^{\mathrm{a}}$ & $7.4 \pm 0.04^{a}$ & $6.3 \pm 0.07^{c}$ & $8.9 \pm 0.03^{a}$ & $8.3 \pm 0.05^{a}$ & $8.2 \pm 0.02^{\mathrm{a}}$ & $9.2 \pm 0.03^{a}$ & $9.4 \pm 0.02^{\mathrm{a}}$ & $8.3 \pm 0.05^{b}$ \\
\hline $\begin{array}{c}\text { Overall } \\
\text { acceptance }\end{array}$ & $8.5 \pm 0.03^{a}$ & $9.2 \pm 0.04^{\mathrm{a}}$ & $8.6 \pm 0.04^{a}$ & $7.8 \pm 0.03^{a}$ & $7.8 \pm 0.01^{a}$ & $8.4 \pm 0.03^{a}$ & $7.6 \pm 0.05^{c}$ & $9.1 \pm 0.03^{a}$ & $8.5 \pm 0.04^{b}$ \\
\hline
\end{tabular}

Table 1: Sensory evaluation for red raspberry-whipped cream, red raspberry-sponge cake and red raspberry-yogurt.

\begin{tabular}{|c|c|c|c|c|}
\hline Proximate composition $\mathbf{( g / 1 0 0 ~ g ~ F W ) ~}$ & Red raspberry fruit & Whipped cream & Yoghurt \\
\hline Moisture & $81.43 \pm 2.06$ & $61.53 \pm 2.58$ & $87.71 \pm 2.73$ \\
\hline Ash & $0.51 \pm 0.08$ & $0.14 \pm 0.07$ & $0.79 \pm 0.08$ \\
\hline Lipid & $0.57 \pm 0.12$ & $33.07 \pm 1.07$ & $1.22 \pm 0.14$ \\
\hline Protein & $1.49 \pm 0.24$ & $1.64 \pm 0.32$ & $3.26 \pm 0.22$ \\
\hline Fiber & $1.59 \pm 0.68$ & $0.23 \pm 0.04$ & $3.42 \pm 0.41$ \\
\hline TC & $14.41 \pm 1.63$ & $3.39 \pm 0.24$ & $0.21 \pm 0.09$ \\
\hline
\end{tabular}

FW: Fresh Weight; DW: Dry Weight; TC: Total Carbohydrates; Values (Mean \pm SD)

Table 2: Proximate composition of red raspberry, whipped cream (with $10 \%$ red raspberry), yoghurt (with $10 \%$ red raspberry) and sponge cake (with $15 \%$ red raspberry). 
Citation: Darwesh AZ, Bayomy H, Rozan M (2016) Effect of Baked, Whipped and Fermentation on Antioxidant Activity in Red Raspberries. J Food Process Technol 7: 621. doi: 10.4172/2157-7110.1000621

Page 4 of 5

\begin{tabular}{|c|c|c|c|c|}
\hline Compound(ug/g) & Red raspberry & Sponge cake & Whipped cream & Yoghurt \\
\hline Gallic acid & $63.929 \pm 3.000$ & $35.497 \pm 4.000$ & $19.365 \pm 2.000$ & $16.996 \pm 2.000$ \\
\hline Protochatchuic acid & $11.320 \pm 1.000$ & $4.814 \pm 0.300$ & $17.172 \pm 5.300$ & $28.343 \pm 5.300$ \\
\hline Gentisic acid & $0.965 \pm 0.070$ & ND & ND & ND \\
\hline Catachine & $46.162 \pm 5.100$ & $34.079 \pm 6.000$ & $37.875 \pm 6.200$ & $31.966 \pm 4.000$ \\
\hline Chlorgenic acid & ND & ND & ND & ND \\
\hline Caffeic acid & $4.073 \pm 0.400$ & $3.511 \pm 0.200$ & $2.458 \pm 0.100$ & $2.156 \pm 0.300$ \\
\hline Syrngic acid & ND & $0.467 \pm 0.030$ & ND & ND \\
\hline Vanillic acid & $1.832 \pm 0.100$ & $22.803 \pm 0.300$ & $2.938 \pm 0.100$ & $0.907 \pm 0.400$ \\
\hline Rutin & ND & ND & ND & ND \\
\hline Coumarin & $38.617 \pm 5.000$ & $29.571 \pm 0.300$ & $12.032 \pm 1.00$ & $10.680 \pm 1.000$ \\
\hline Ferulic acid & $8.342 \pm 0.300$ & $1.061 \pm 0.100$ & $2.991 \pm 0.002$ & $2.058 \pm 0.003$ \\
\hline Sinapic acid & $4.722 \pm 0.006$ & $3.094 \pm 0.300$ & $1.453 \pm 0.001$ & $1.542 \pm 0.001$ \\
\hline Rosmarinic acid & $2.150 \pm 0.003$ & $0.751 \pm 0.006$ & ND & $0.569 \pm 0.004$ \\
\hline Cinnamic acid & $1.274 \pm 0.004$ & $1.334 \pm 0.400$ & $0.530 \pm 0.003$ & $0.582 \pm 0.002$ \\
\hline Qurecetin & $0.537 \pm 0.003$ & ND & $0.499 \pm 0.003$ & $0.169 \pm 0.003$ \\
\hline Kaempferol & $0.709 \pm 0.005$ & $0.398 \pm 0.002$ & $2.717 \pm 0.3$ & $0.189 \pm 0.001$ \\
\hline Chyrsin & $3.647 \pm 0.004$ & $3.075 \pm 0.200$ & $4.873 \pm 0.300$ & $2.090 \pm 0.200$ \\
\hline
\end{tabular}

Mean \pm standard deviation $(n=3)$

Table 3: Contents of main phenolic compounds of red raspberry, raspberry-sponge cake, raspberry-whipped cream and raspberry-yogurt by HPLC.

\begin{tabular}{|c|c|c|c|}
\hline Sample & Total phenols $\mathbf{( m g ~ G A E} / \mathbf{g})$ & Total flavonoids (mg CE/g) & DPPH $(\mathbf{m g}$ TE/g) \\
\hline Red raspberry & $1.088 \pm 0.02$ & $0.216 \pm 0.003$ & $2.270 \pm 0.5$ \\
\hline Yoghurt & $0.067 \pm 0.05$ & $0.026 \pm 0.001$ \\
\hline Whipped cream & $0.081 \pm 0.004$ & $0.069 \pm 0.001$ & $0.289 \pm 0.07$ \\
\hline Sponge cake & $0.709 \pm 0.08$ & $0.151 \pm 0.004$ \\
\hline Mean \pm standard deviation $(n=3)$. & & $0.591 \pm 0.03$ \\
\hline
\end{tabular}

Mean \pm standard deviation $(n=3)$

Table 4: Total phenols, total flavonoids and DPPH of red raspberry, raspberry-sponge cake, raspberry-whipped cream and raspberry-yogurt.

acid, catachine, coumarin and protochatchuic acid, respectively in the red raspberry. On the other hand, gallic acid, catachine, coumarin and vanillic acid were recorded $35.497 \pm 4.000,34.079 \pm 6.000,29.571 \pm$ 0.300 and $22.803 \pm 0.300 \mathrm{ug} / \mathrm{g}$ respectively in the red raspberry- sponge cake. The higher TPC in the red raspberry-whipped cream were 37.875 $\pm 6.200,19.365 \pm 2.000$ and $17.172 \pm 5.300$ and $12.032 \pm 1.00 \mathrm{ug} / \mathrm{g}$ of catachine, gallic acid, protochatchuic acid and coumarin, respectively. The highest TPC found in red raspberry-yoghurt were $31.966 \pm 4.000$ $28,343 \pm 5.300,16.996 \pm 2.000$ and $10.680 \pm 1.000 \mathrm{ug} / \mathrm{g}$ of catachine, protochatchuic acid, gallic acid and coumarin, respectively. Adding raspberry to the product are attributed the most significant health benefits of to the phenolic compounds, such as flavonoids, phenolic acids [47]. So the treatments were order in general to their effect of the TPC: fermentation $>$ whipped $>$ baked.

\section{DPPH scavenging activity}

Red raspberry-sponge cake had higher antioxidant activity than red raspberry-whipped cream and raspberry-yogurt (Table 3). Highest $\mathrm{DPPH}$ in red raspberry-sponge cake than in red raspberry -whipped cream and red raspberry-yogurt were most likely contributed by individual phytochemical contents and as a result of microbial metabolic activities [48]. The lowest in yoghurt may be due to attributed to the metabolically active yogurt bacteria [49]. High antioxidant activities useful for protective cardiovascular effect [50]. The DPPH radicalscavenging highest with heat followed by whipped and fermentation. The DPPH radical-scavenging activity was $0.591,0.353$ and $0.289 \mathrm{mg}$ $\mathrm{TE} / \mathrm{g}$ of red raspberry-sponge cake, red raspberry-whipped cream and red raspberry-yogurt respectively (Table 4).

\section{Total flavonoids}

Table 2 shows that the baking treatment had higher total flavonoids than the whipping and fermentation. The mean values of red raspberry were $0.216 \pm 0.003 \mathrm{mg} \mathrm{CE} / \mathrm{g}$ followed by red raspberry-sponge cake value $0.151 \pm 0.004 \mathrm{mg} \mathrm{CE} / \mathrm{g}$ and red raspberry-whipped cream 0.069 $\pm 0.001 \mathrm{mg} \mathrm{CE} / \mathrm{g}$, while yoghurt was recorded lowest value $0.026 \pm$ $0.001 \mathrm{mg} \mathrm{CE} / \mathrm{g}$. flavonoid compounds of raspberry have significant antioxidant activities consumption may help prevent and/or moderate chronic diseases these antioxidant properties and health benefits and for tailored breeding for functional foods [51].

\section{Conclusion}

Red raspberry sponge cake could be further used as a source of natural antioxidants for application in the nutraceutical or functional food areas. Much higher losses of total phenols were found in baked, whipped and fermentation treatment. A strong effect of treatment on phenols content was found in fermentation treatment. The products produced with red raspberry contained $56 \%, 37 \%$ and $4 \%, 3 \%$ of raspberry total phenols of red raspberry, red raspberry -yoghurt, red raspberry -whipped cream and red raspberry-sponge cake.

\section{References}

1. Harauma A, Murayama T, Ikeyama K, Sano H, Arai K, et al. (2007) Mulberry leaf powder prevent atherosclerosis in apolipoprotein E-deficient mice. Biochem Biophys Res Commun 358: 751-756.

2. Quideau S, Feldman KS (1996) Ellagitannin chemistry. Chem Rev 96: 475-504

3. Clifford MN, Scalbert AE (2000) Nature occurrence and dietary burden. J Sci Food Agric 80; 1118-1125.

4. Kahkonen MP, Hopia Al, Heinonen M, Berry S (2001) Phenolics and their antioxidant activity. J Agric Food Chem 49: 4076-4082.

5. Mullen W, McGinn J, Lean MEJ, MacLean MR, Gardner P, et al. (2002) Ellagitannins, flavonoids and other phenolics in red raspberries and their contribution to antioxidant capacity and vaso-relaxation properties. J Agric Food Chem 50: 5191-5196. 
Citation: Darwesh AZ, Bayomy H, Rozan M (2016) Effect of Baked, Whipped and Fermentation on Antioxidant Activity in Red Raspberries. J Food Process Technol 7: 621. doi: 10.4172/2157-7110.1000621

6. Okuda T, Yoshida T, Hatano T (1989) Ellagitannins as active constituents of medicinal plants. Planta Med 55: 117-122.

7. Beekwilder J, Jonker H, Meesters P, Hall R, Meer IM, et al. (2005) Antioxidants in raspberry on-line analysis links antioxidant activity to a diversity of individual metabolites. J Agric Food Chem 53: 3313-3320.

8. Namiesnik J, Vearasilp K, Nemirovski A, Leontowicz $\mathrm{H}$, Leontowicz $\mathrm{M}$, et al. (2014) In vitro studies on the relationship between the antioxidant activities of some berry extracts and their binding properties to serum albumin. Appl Biochem Biotechnol 172: 2849-2865.

9. Skrovankova S, Sumczynski D, Mlcek J, Jurikova T, Sochor J, et al. (2015) Bioactive compounds and antioxidant activity in different types of berries. Int $J$ Mol Sci 16: 24673-24706.

10. Aramwit P, Bang N, Srichana T (2010) The properties and stability of anthocyanins in mulberry fruits. Food Res. Int 43: 1093-1097.

11. Paweł G, Karina JR, Vitalijs $R$, Inga $P$, Iveta $P$ (2016) The impact of different baking conditions on the stability of the extractable polyphenols in muffins enriched by strawberry sour cherry raspberry or black currant pomace. LWTFood Sci Technol 65: 946-953.

12. Su MS, Chien PJ (2007) Antioxidant activity anthocyanins and phenolics of rabbit-eye blueberry (Vaccinium ashei) fluid products as affected by fermentation. Food Chemistry 104: 182-187.

13. Cabrita L, Fossen T, Andersen OM (2000) Colour and stability of the six common anthocyanidin 3-glucosides in aqueous solutions. Food Chemistry 68 : 101-107.

14. Nielsen ILF, Haren GR, Magnussen EL, Dragsted LO, Rasmussen SE, et al. (2003) Quantification of anthocyanins in commerce black currant juices by simple high-performance liquid chromatography. Investigation of their $\mathrm{pH}$ stability and antioxidative potency. J Agricultural and Food Chemistry 51: 5861-5866.

15. Devi PSSM, Mohandas S (2012) The effects of temperature and pH on stability of anthocyanins from red sorghum (Sorghum bicolor) bran. African J Food Sci 6: 567-573.

16. Borkowski T, Szymusiak H, Gliszczynska-Swiglo A, Rietjens IMCM, Tyrakowska B, et al. (2005) Radical scavenging capacity of wine anthocyanins is strongly pH-dependent. J Agricultural and Food Chemistry 53: 5526-5534.

17. Giusti MM, Wrolstad RE (2003) Acylated anthocyanins from edible sources and their applications in food systems. Biochemical Engineering Journal 14 217-225.

18. Delgados-Vargas F, Paredes-López O (2003) Pigments as colourants. In natural colourants for food and nutraceutical uses. CRC Press: Boca Raton, London, New York, Washington DC.

19. Cevallos-Casals BA, Cisneros-Zevallos L (2004) Stability of anthocyaninbased aqueous extracts of Andean purple corn and red fleshed sweet potato compared to synthetic and natural colorants. Food Chem 86: 69-77.

20. Fan G, Han Y, Gu Z, Gu F (2008) Composition and colour stability of anthocyanins extracted from fermented purple sweet potato culture. LWT-Food Sci Tech 41: 1412-1416.

21. Bridle P, Timberlake CF (1997) Anthocyanins as natural food colors selected aspects. Food Chem 58: 103-109.

22. Wallace TC, Giusti MM (2008) Determination of color pigment and phenolic stability in yogurt systems colored with nonacylated anthocyanins from Berberis boliviana $\mathrm{L}$ as compared to other natural/synthetic colorants. J Food Sci 73: $241-248$

23. Rommel A, Wrolstad RE (1993) Influence of acid and base hydrolysis on the phenolic composition of red raspberry juice. J Agric Food Chem 41:1237-1241.

24. Turkben C, Sarıburun E, Demir C, Uylaser V (2010) Effect of freezing and frozen storage on phenolic compounds of raspberry and blackberry cultivars. Food Anal Methods. 3: 144-153.

25. Hakkinen SH, Karenlampi SO, Heinonen IM, Mykkanen HM, Torronen AR, et al. (1998) HPLC method for screening of flavonoids and phenolic acids in berries. J Agric Food Chem; 77: 543-551.

26. Seeram NP, Adams LS, Zhang Y, Lee R, Sand D, et al. (2006) Black-berry black raspberry blueberry cranberry red raspberry and strawberry extracts inhibit growth and stimulate apoptosis of human cancer cell in vitro. J Agric Food Chem 54: 329-339.

27. Seeram NP (2008) Berry fruits compositional elements biochemical activities and the impact of their intake on human health performance and disease. $J$ Agric Food Chem 56: 627-629.
28. Wu X, Liang L, Zou Y, Zhao T, Zhao J, et al. (2010) Aqueous two-phase extraction, identification and antioxidant activity of anthocyanins from mulberry (Morus atropurpurea Roxb.) Food Chem 2: 443-453.

29. Chaiya B, Pongsawatmanit R (2011) Quality of batter and sponge cake prepared from wheat-tapioca flour blends. Kasetsart J Nat Sci 45: 305-313.

30. AOAC (2000) Association of official analytical chemists. (17thedn). Official method of analysis Washington D.C., USA.

31. Christie WW (1983) Lipids. In: Aliphatic and related natural product chemistry (2ndedn) Pergamon Press Oxford.

32. Kjeldahl $\mathrm{J}$ (1983) Determination of protein nitrogen in food products. Encyc Food Agric 28: 757-765.

33. Imran M, Khan H, Hassan SS, Khan R (2008) Physico-chemical characteristics of various milk samples available in Pakistan. J Zhejiang Univ Sci B 9: 546-551.

34. Muler HG, Tobin G (1980) Nutrition of food processing. Croom Helm Ltd London.

35. Zilic S, Serpen A, Akıllıglu G, Jankovic M, Gökmen V (2012) Distributions of phenolic compounds yellow pigments and oxidative enzymes in wheat grains and their relation to antioxidant capacity of bran and debranned flour. $\mathrm{J}$ of Cereal Sci 56: 652-658.

36. Hwang ES, Do-Thi N (2014) Effects of extraction and processing methods on antioxidant compound contents and radical scavenging activities of lave (Porphyra tenera). Prev Nutr Food Sci 19:40-48.

37. Kim KH, Tsao R, Yang R, Cui SW (2006) Phenolic acid profiles and antioxidant activities of wheat bran extracts and the effect of hydrolysis conditions. Food Chemistry 95: 466-473.

38. Stone H, Sidel JL (1993) Sensory evaluation practices (2ndedn), Academic press San Diego CA

39. Patras A, Brunton NP, O'Donnell C, Tiwari BK (2010) Effect of therma processing on anthocyanin stability in foods mechanisms and kinetics of degradation. Trends Food Sci Technol 21: 3-11.

40. Dinstel RR, Cascio J, Koukel S (2013) The antioxidant level of Alaska's wild berries high higher and highest. International J Circumpolar Health.

41. Rudy S, Dziki D, Krzykowski A, Gawlik-Dziki U, Polak R, et al. (2015) Influence of pre-treatments and freeze-drying temperature on the process kinetics and selected physico-chemical properties of cranberries (Vaccinium macrocarpon Ait.). LWT Food Sci Technol 63: 497-503.

42. Lindenmeier M, Hofmann T (2004) Influence of baking conditions and precursor supplementation on the amounts of the antioxidant pronyl--Iysine in bakery products. J Agricultural and Food Chem 52: 350-354.

43. McDougall GJ, Dobson P, Jordan-Mahy N (2010) Effect of different cooking regimes on rhubarb polyphenols. Food chem 119: 758-764.

44. Miller KB, Stuart DA, Smith NL, Lee CY, Mchale NL, et al. (2006) Antioxidant activity and polyphenol and procyanidin contents of selected commercially available cocoa-containing and chocolate products in the USA. J Agricultural and Food Chem 54: 4062-4068.

45. Blum U (1998) Effects of microbial utilization of phenolic acids and their phenolic acid breakdown products on allelpathic interactions. J Chemical Ecology 24: 685-708.

46. Amirdivani S, Baba AS (2011) Changes in yogurt fermentation characteristics, and antioxidant potential and in vitro inhibition of angiotensin-1 converting enzyme upon the inclusion of peppermint dill and basi. Food Science and Technology 44: 1458-1464.

47. Paredes-López O, Cervantes-Ceja ML, Vigna-Pérez M, Hernández-Pérez $\mathrm{T}$ (2010) Berries improving human health and healthy aging and promoting quality life - A Review. Plant Foods for Human Nutrition 65: 299-308.

48. Thompson JL, Lopetcharat K, Drake MA (2007) Preferences for commercia strawberry drinkable yogurts among African American, Caucasian, and Hispanic consumers in the USA. J Dairy Sci 90: 4974-87.

49. Papadimitriou CG, Mastrojiannaki AV, Silva AV, Gomes AM, Malcata F (2007) Identification of peptides in traditional and probiotic sheep milk yoghurt with angiotensin I-converting enzyme (ACE)-inhibitory activity. Food Chemistry 105: 647-56.

50. Massey LK (2001) Dairy food consumption blood pressure and stroke. J Nutrition 131: 1875-1878.

51. Bradish CM, Perkins-Veazie P, Fernandez GE, Xie G, Jia W (2012) Comparison of flavonoid composition of red raspberries (Rubus idaeus L.) grown in the southern United States. J Agric Food Chem 60: 5779-5786. 